\title{
Lack of relationship between fasting plasma citrulline and glucose absorption: do not underestimate the role of the failing kidney!
}

\author{
Patrick M. Honore ${ }^{1 *}$, David De Bels ${ }^{1}$, Andrea Gallerani ${ }^{1}$, Rachid Attou ${ }^{1}$ and Willem Boer ${ }^{2}$ \\ See related research by Poole et al., https://ccforum.biomedcentral.com/articles/10.1186/s13054-014-0725-4.
}

Poole et al. published in a relatively recent paper in Critical Care concluding that, while both plasma citrulline concentrations and glucose absorption were reduced in critical illness, fasting plasma citrulline concentrations were not predictive of subsequent glucose absorption and therefore do not appear to be a marker of small intestinal absorptive function [1]. It is argued that the degree of reduction in citrulline concentration may be curtailed by renal dysfunction. Cynober [2] demonstrated that citrulline is mainly metabolized by the kidney, where it is converted into arginine by cells of the proximal tubules [2]. Approximately $83 \%$ of the citrulline released by the gut is metabolized within the kidney [2]. Synthesized arginine is released into the general blood circulation. In adults, the citrulline converted by the kidney is enough to provide the body's full arginine requirements. Arginine synthesized from citrulline represents $60 \%$ of the de novo arginine synthesis in the organism [2]. In the Poole study, four patients out of 20 $(20 \%)$ were in acute kidney injury (AKI) with a creatinine level $>100 \mu \mathrm{mol} / \mathrm{L}$. These were therefore unable to metabolize a large part of the citrulline released by the gut, hindering interpretation of mean citrulline levels as blunting of the relationship between fasting plasma citrulline concentrations and glucose adsorption is likely. Ware et al. [3] described low levels of citrulline in severe sepsis and a concomitant association with acute respiratory distress syndrome (ARDS). Cynober commented on the Ware publication [4] that, despite the fact that $41 \%$ of patients were in AKI, no difference was demonstrated between patients with or without AKI, attributing the

\footnotetext{
* Correspondence: Patrick.Honore@CHU-Brugmann.be

${ }^{1}$ ICU Department, Centre Hospitalier Universitaire Brugmann-Brugmann University Hospital, Place Van Gehuchtenplein,4, 1020 Brussels, Belgium
} Full list of author information is available at the end of the article absence of expected increase in citrulline levels in AKI to an unknown covariable (for example, gut failure) decreasing citrulline levels [4]. In one study, citrulline $(\mathrm{MW}=15 \mathrm{kDa})$ was reduced by $55 \%$ in a session of 90 min of intermittent hemodialysis (IHD) [5]. Continuous renal replacement therapy (CRRT) will likely extract citrulline more efficiently. Of the $41 \%$ who were in AKI in the Ware study, half could be expected to be on some forms of renal replacement therapy (RRT), explaining the low citrulline levels in the AKI group. We conclude that patients with AKI or chronic kidney disease (CKD), causing citrulline increase, and patients on RRT, causing a decrease, should be excluded from studies.

\section{Abbreviations \\ AKI: Acute kidney injury; ARDS: Acute respiratory distress syndrome; CKD: Chronic kidney disease; CRRT: Continuous renal replacement therapy; IHD: Intermittent hemodialysis; RRT: Renal replacement therapy}

\section{Acknowledgements}

None.

\section{Funding}

None.

\section{Availability of data and materials Not applicable.}

\section{Authors' contributions \\ $\mathrm{PMH}$ and WB designed the paper. All authors participated in drafting and reviewing. All authors read and approved the final version of the manuscript.}

Ethics approval and consent to participate Not applicable.

\section{Consent for publication \\ Not applicable.}

\section{Competing interests}

The authors declare that they have no competing interests. 


\section{Publisher's Note}

Springer Nature remains neutral with regard to jurisdictional claims in published maps and institutional affiliations.

\section{Author details}

${ }^{1}$ ICU Department, Centre Hospitalier Universitaire Brugmann-Brugmann University Hospital, Place Van Gehuchtenplein,4, 1020 Brussels, Belgium.

${ }^{2}$ Dept. of Anesthesiology, Intensive Care Medicine, Emergency Medicine \&

Pain Medicine, Ziekenhuis Oost-Limburg, Genk, Belgium.

Received: 4 February 2019 Accepted: 28 February 2019

Published online: 11 April 2019

\section{References}

1. Poole A, Deane A, Summers M, Fletcher J, Chapman M. The relationship between fasting plasma citrulline concentration and small intestinal function in the critically ill. Crit Care. 2015;19:16. https://doi.org/10.1186/ s13054-014-0725-4

2. Curis E, Nicolis I, Moinard C, Osowska S, Zerrouk N, Bénazeth S, et al. Almost all about citrulline in mammals. Amino Acids. 2005;29(3):177-205 Epub 2005 Aug 8. Review.

3. Ware LB, Magarik JA, Wickersham N, Cunningham G, Rice TW, Christman BW, et al. Low plasma citrulline levels are associated with acute respiratory distress syndrome in patients with severe sepsis. Crit Care. 2013;17(1):R10. https://doi.org/10.1186/cc11934.

4. Cynober L. Citrulline: just a biomarker or a conditionally essential amino acid and a pharmaconutrient in critically ill patients? Crit Care. 2013;17(2): 122. https://doi.org/10.1186/cc12534.

5. McBryde KD, Kudelka TL, Kershaw DB, Brophy PD, Gardner JJ, Smoyer WE. Clearance of amino acids by hemodialysis in argininosuccinate synthetase deficiency. J Pediatr. 2004;144(4):536-40. 